\title{
Motion to education for sustainable development
}

\author{
Vega V. Pustovalova ${ }^{1, *}$ and Tatiana V. Avgusmanova ${ }^{2}$ \\ ${ }^{1}$ Information and Methodical Center, director, Tomsk, Russia \\ ${ }^{2}$ IFTE, the Center of Scientific and Methodological Support of the Federal State Educational Standards, Introduction and \\ Implementation, Irkutsk, Russia
}

\begin{abstract}
The new ideology of education for sustainable development requests comprehension. The analysis is needed to understand the following: where are we now and where should be? What are the growing points? The key point in the analysis is seen as the answer to the question what qualitative resources in school can be used and developed for education for sustainable development. In that context among other things it is essential to consider pedagogical potentialities of project activity and its development by means of cognitive metaphor possessing heuristic, motivational, evaluative and other potentials. It requires new structures of didactic unit in education for sustainable development including objectification of «environmental axiom» metaphorical thought form of ecological imperative. (E.N. Dzyatkovskaya).
\end{abstract}

The originality of education for sustainable development is extensive and requires comprehension.

The object of the paper is to define the abilities of students' project activity renovation by means of heuristic, motivational, cognitive, evaluative and other potentials of cognitive metaphor.

Project activity is traditionally carried out among gifted children as unnecessary; it can be compared with optional tasks of higher level [1]. In the Federal State Educational Standard the basis formation of project activity or academic and research activity is presented as a compulsory result. All participants of learning process must be included into school work system in given direction. The renovation of students' project activity organization is proposed at the cost of integrative models of all teaching staff activity. In project activity system establishing by teachers from primary to secondary school the following is coordinated:

1. Steering documents and course scheduling for school subjects are the questions of continuation in project activity or academic and research activity formation. Teachers' activities in the same class, results, academic and research activity simultaneous establishment are verified. Common approaches (procedures, questionnaires) are defined.

2. The integration of curricular and extracurricular activities. The role of extracurricular course (e.g. «Basis of Project Activity») as a methodological framework familiarization. Project activity courses in fifth and sixth grades as a project activity propaedeutics. Project check list of school subjects, integrated courses, group project check list and its implementation in different curricular and extracurricular courses are defined.

3. Rating system of intended learning outcomes in progress of group projects (communicative, regulative, cognitive universal learning activities, ICT competency, text manipulation et cetera).

4. Students' progress monitoring in the course of academic and research or project activities. (project diary, accomplishment sheet, procedures, rules of collaboration et cetera).

5. Formative assessment mechanism aimed to selfassessment and self-consciousness development in progress of project. How formative assessment can be used in project activity rating.

6. Midterm and final educational events, examinations.

7. Information, organization, material and technical environment for students' academic and research or project activities (information resources, workshops, school research communities et cetera).

8. Integration of school research community working schedule with students' project activity.

The list given above can be improved taking into account context information of school development.

Capabilities of project activity can make it possible to reflect its place in education for sustainable development. Elena Dzyatkovskaya in her monograph considers project activity through the new structures of didactic unit in education for sustainable development. It includes the objectification of «environmental axiom» metaphorical thought form of ecological imperative using educational material chosen and analyzed by student getting information from curricular and extracurricular activities. That is the metaphor interpretation, searching for «unobvious» in it. Any student has an individual and different set of information depended on individual aptitude (individual sphere of concepts, metaphor interpretation as a level of cultural concept comprehension) [2].

\footnotetext{
*Corresponding author: vega 2005 11@mail.ru
} 
To understand the updating of project activity based on metaphor we can study metaphor role in scientific cognition. The main idea is that «metaphor is an essential attribute of scientific research in any domain area» (A.F. Zakirova) [3]. According to A.F. Zakirova, S.S. Gusev and G.L. Tul'chinskii the orientation to metaphor comprehension is important in scientific theories. As metaphor affords to express in language which means to make conscious new information about the world at such stages of scientific cognition as:

- problem statement at a totally new level,

- appearing of research borderland,

- parallel detecting between different research methods et cetera [3]

It is inappropriate to compare scientific cognition and project activity comprehension by student, nevertheless metaphor as a heuristic, motivational and estimative resource is considered actual. The range of pro arguments in favor of metaphor is wide. General purpose knowledges and abstractly summarized characteristics for student are not all-sufficient. Functional usage as a base of students' progress demands correlation with empirical practice, knowledge and first-hand experience. It can be achieved in learning process using metaphor. «Student must recognize the essence of the phenomenon under study through metaphor. It must be figurative and highly charged. Metaphor must be ingrained, must define thinking style and appear guideline to follow» [4].

In other words, metaphor makes the material under consideration more realistic and intelligible for student. It stimulates reflexive activity of students' cognition.

In pedagogics metaphor usage in project activity is not insufficiently investigated. Although it provides perception simplicity of object under research and interpretation variety faced first-hand experience and self-appreciation.

Considering research activity of theoretical and empirical levels, A.I. Savenkov emphasizes components of project activity which are the reflexion of implementation stages, description of means and procedures using while investigating. One of the components, skill to work with metaphor provides for comprehending of expressions metaphorical sense and understanding or constructing turns of speech using concealed framing, figural approximation of words.

This is not about existing metaphor comprehension, but also about skills of metaphor coinage and adequate selecting. Metaphor belongs not only to linguistic field but can be expressed both in words (She has come to a crossroads in her life) and non-verbal (paintings, music, gestures et cetera) ${ }^{1}$. In learning process different types of conceptual metaphor can be used: verbal or nonverbal - visual, phonic, motorial and haptic. Skills to create or perceive verbal texts and graphic means (diagrams, pictograms, Information graphics).

Metaphor is considered as a pedagogical tool. On the one hand, it allows student to expand cognition context (discover and prove), to strengthen connection with his individual language sphere of concepts (metaphor as a linguistic means) and with empirical practice, stored knowledge and experience (metaphor as a cognitive mechanism). On the other hand, it is valuable because it provides qualimetric assessment of project activity, reflexive, subjectively personal enhancement in grasp of reality and/or teaching information, readiness to get into textbook content creatively.

Consequently, metaphor is a pedagogical tool and output and/or outcome of project activity.

The pole-star in project activity is metaphor which «trenches upon invisible worlds zone (interior life), secondary predicate zone, comprehensive collocations zone, sophisticated semantics predicates zone» [5]

Requested cognitive, heuristic, ethical, aesthetic, pragmatic and other metaphor functions determinate students' support by teacher in project activity. Class project can be used as knowledge assessment. For instance, in conclusion of topic «Safety is a human being's basic need» in course «Ecology and Life Safety» [6]. The task: In hunter's life nets image from the beginning was connected with bare subsistence procurement. Fish net, net dodge for catching birds et cetera. Word «net» attribute as dozens connection is used on the Internet (e.g. Webciety) in system of connected computers (local area network) et cetera. But the collocation «networking» has a negative emotional colour connected with capture or danger in a particular context. «Networking life» or life in computer networks? Real life or online life? Do computer games threaten human safety?

Thus, the abilities of project activity renovation by means of heuristic, motivational, cognitive, and evaluative and other potentials of cognitive metaphor demands careful thoughts.

\section{References}

1. V.V. Pustovalova, Gif. Ch., 1 (2008) [In Rus]

2. E.N. Dzyatkovskaya, Obrazovanie dlya ustoychivogo razvitiya $v$ shkole. Kul'turnye kontsepty. "zelenye aksiomy». Transdistsiplinarnost': monofraphiya (Educ. and Ecol. Publ., Moscow, 2015) [In Rus]

3. S.S. Gusev., G.L.Tul'chinskiy, Problema ponimaniya $v$ philosophii (Politizdat, Moscow, 1985) [In Rus]

4. M.A. Ahmetov, and Eh.A Musenova, Tekhniki upravleniya uchebnoy deyatel'nost'yu uchashikhsya Available online: URL http://www.eidos.ru/journal/2008/0407.htm) (Accessed 03.04.2016) [In Rus]

5. N.D. Arutyunova, Yazyk i mir cheloveka [Russkii Yazyk, Moscow, 1999) [In Rus]

6. E.N. Dzyatkovskaya, Ekologiya i bezopastnost' zhiznedeyatel'nosti 4 (2013) Available online: URL http://cyberleninka.ru/article/n/o-kontseptsiiintegrirovannogo-kursa-dlya-starsheklassnikovekologiya-i-bezopasnostzhiznedeyatelnosti) (Accessed 03.04.2016) [In Rus] 